\title{
Neoplastic Small Cell
}

National Cancer Institute

\section{Source}

National Cancer Institute. Neoplastic Small Cell. NCI Thesaurus. Code C37103.

A benign or malignant cell that is characterized by the presence of a small nucleus and scant amount of cytoplasm. It may be epithelial, lymphoid, neuroepithelial, or mesenchymal in origin. 